\title{
KEMAMPUAN MEMPRODUKSI TEKS EKSPLANASI BERDASARKAN ISI, STRUKTUR DAN CIRI KEBAHASAAN OLEH SISWA KELAS XI SMK MULTI KARYATAHUN PEMBELAJARAN 2016/2017
}

\author{
Oleh \\ Asnah Meriati Tamba \\ Fitriani Lubis, S.Pd, M.Pd.
}

\begin{abstract}
Penelitian ini bertujuan untuk mengetahui dan mendeskripsikan kemampuan memproduksi teks eksplanasi berdasarkan isi, struktur dan ciri kebahasaan oleh siswa kelas XI SMK Multi Karya tahun pembelajaran 2016/2017. Populasi penelitian ini adalah seluruh siswa kelas XI SMK Multi Karya tahun pembelajaran 2016/2017 yang terdiri dari 11 kelas dan berjumlah 358 orang.Sampel penelitian ini diambil dengan cara random sampling. Sampel penelitan diambil $10 \%$ dari populasi sehingga sampel penelitian ini adalah 40 orang siswa.Metode yang digunakan dalam penelitian ini adalah metode deskriptif kulitatif, yaitu mendeskripsikan suatu keadaan alamiah mengenai kegiatan memproduksi teks eskplanasi siswa kelas XI SMK Multi Karya. Instrumen yang digunakan untuk memperoleh data adalah tes essay. Data penelitian menunjukkan bahwa kemampuan siswa dalam memproduksi teks eksplanasi memiliki nilai ratrata (mean) 68,25 dan berada pada kategori cukup. Hal ini dapat dilihat dari rentang nila 86-100 dengan kategori sangat baik diperoleh sebanyak 2 orang (5\%), rentang nilai 76-85 dengan kategori baik diperoleh sebanyak 14 orang (35\%), rentang nilai 56-75 dengan kategori cukup diperoleh sebanyak 18 orang (45\%), dan rentang 10-55 dengan kategori kurang diperoleh sebanyak 6 orang $(15 \%)$.Berdasarkan analisis data diatas maka dapat disimpulkan bahawa kemampuan memproduksi teks eksplanasi pada siswa kelas XI SMK Multi Karya Tahun Pembelajaran 2016/2017 masih termasuk dalam kategori cukup.
\end{abstract}

Kata Kunci :isi, struktur, ciri kebahasaan, teks eksplanasi

\section{PENDAHULUAN}

Pendidikan di Indoneisa menempatkan bahasa Indonesia sebagai salah satu bidang studi yang diajarkan disekolah. Pengajaran bahasa Indonesia haruslah berisi usaha-usaha yang dapat membawa serangkai keterampilan.Salah satu pengajaran bahasa Indonesia di SMA (Sekolah Menengah Atas) adalah siswa mampu menikmati, memahami dan memanfaatkan karya sastra dengan tujuan mengembangkan kepribadian, memperluas wawasan kehidupan serta meningkatkan kemampuan berbahasa. Kemampuan (keterampilan) 
berbahasa terdiri dari empat komponen yaitu kemampuan menyimak, keterampilan berbicara, keterampilan membaca, dan keterampilan menulis.

Salah satu bagian dari kompetensi inti yang terdapat dalam silabus SMA kelas XI dalam kurikulum 2013 adalah (4) mengolah, menalar, dan menyaji dalam ranah konkret dan ranah abstrak terkait dengan pengembangan diri yang dipelajarinya di sekolah secara mandiri, bertindak secara efektif dan kreatif, serta mampu menggunakan metode sesuai kaidah keilmuan dan terfokus pada kompetensi dasar (4.4) yang membahas mengenai menulis teks eksplanasi yaitu. Memproduksi teks eksplanasi secara lisan atau tulisan dengan memperhatikan isi, struktur dan kebahasaan.Teks eksplanasi merupakan sebuah jenis teks yang menjelaskan mengenai sebuah kejadian atau fenomena alam, sosial, ilmu pengetahuan yang diceritakan kembali berdasarkan keadaan yang sesungguhnya terjadi. Mahsun (2014:33) mengatakan "Teks eksplanasi adalah teks yang mempunyai fungsi sosial menjelaskan atau menganalisis proses muncul atau terjadinya sesuatu". Kompetensi dasar tersebut harus dicapai oleh siswa kelas XI SMA secara tuntas dan maksimal.

Keterampilan menulis merupakan salah satu keterampilan berbahasa yang bermanfaat bagi kehidupan manusia, khususnya para siswa.Pada saat menulis, siswa dituntut berpikir untuk menuangkan gagasan secara tertulis berdasarkan pengetahuan dan pengalaman yang dimiliki. Dalman (2014: 3) mengemukakan bahwa menulis merupakan suatu kegiatan komunikasi berupa penyampaian pesan (informasi) secara tertulis kepada pihak lain dengan menggunakan bahasa tulis sebagai alat atau medianya. Aktivitas menulis melibatkan beberapa unsur, yaitu penulis sebagai penyampai pesan, isi tulisan,saluran atau media, dan pembaca.

Penelitiaan yang dilakukan oleh Martha Novita Sari Lagur dengan judul "Kemampuan Menulis Teks Eksplansi dengan Menggunakan Media Gambar Seri Siswa Kelas VII SMP Negeri 2 Turi, Slaman, Yogyakarta Tahun Pembelajaran 2015/2016" menyatakan bahwa masih banyak siswa mengalami kesulitan dalam hal menulis, para siswa merasa sulit menemukan gagasan atau topik yang akan ditulis. Sekolah tersebut sudah menerapkan kurikulum 2013, salah satunya yang membuat siswa sulit mengembangkan gagasan atau topik karena kurangnya media. Kemudian penelitian yang dilakukan oleh Yulia Ningsih (dalam Jurnal Bahasa dan Sastra Indoneisa, 18 Juli 2014) dengan judul "Kemampuan Menulis Teks Eksposisi Siswa Kelas X SMA Negeri 1 Banten Tahun Pembelajaran 2013/2014" menyatakan di lingkungan formal banyak ditemui siswa kurang terampil dalam menulis seperti pada aspek pilihan kata, penggunaan huruf kapital, penggunaan tanda baca, kesesuaian isi dengan tema dan untuk membuat ide-ide pokok. Hal ini bertujuan untuk 
mengetahui kemampuan siswa dalam menulis teks esposisi sesuai dengan aspek yaitu isi, struktur teks, kosa kata, kalimat dan mekanik.

Bedasarkan hasil penelitian sebelumnya, peneliti juga melakukan wawancara dengan guru bidang studi Bahasa Indonesia disekolah SMK Multi Karya diperoleh data bahwa motivasi belajar siswa masih kurang karena ketika dilakukan diskusi seperti yang dituntut dalam pembelajaran 2013, mereka lebih memilih bermain-main dan tidak serius belajar. Ketika diberi tugas memproduksi, siswa dengan sengaja mengulur waktunya agar tugas memproduksi tersebut menjadi tugas rumah, akibatnya tugas memproduksi dapat disalin dari internet ataupun sumber lain, bukan hasil pemikiran sendiri, kemudian siswa kurang aktif dikarenakan metode pembelajaran yang yang di terapkan dalam kurikulum 2013 belum berjalan dengan baik, nilai siswa mengenai pembelajaran memproduksi teks eksplanasi di bawah KKM, (Kriteria Ketuntasan Minimal). Nilai KKM pada standar kompetensi disekolah tersebut adalah 75. Sedangkan nilai rata-rata siswa kelas XI tahun pembelajaran 2016/2017 pada mata pelajaran Bahasa Indonesia untuk materi memproduksi teks adalah 68. Oleh karena itu pencapaian nilai memproduksi teks siswa belum tuntas (tidak tercapai)

Berdasarkan pada uraian latar belakang di atas, perlu kiranya diadakan suatu penelitian pendidikan.Dalam hal ini, dilakukan penelitian yang berjudul "Kemampuan Memproduksi Teks Eksplanasi Berdasarkan Isi, Struktur, dan Ciri Kebahasaanoleh Siswa Kelas XI SMK Multi Karya Tahun Pembelajaran 2016/2017.”

\section{KEMAMPUAN MEMPRODUKSI TEKS EKSPLANSI}

Salah satu bidang aktivitas dan materi pengajaran bahasa Indonesia di sekolah yang memegang peranan penting adalah pengajaran memproduksi atau menulis. Memproduksi atau menulis merupakan suatu bentuk manifestasi kompetensi berbahasa paling akhir dikuasai pembelajaran bahasa setelah kompetensi mendengar, berbicara, dan membaca. Menulis merupakan proses pengungkapan ide, gagasan, pikiran, maupun perasaan yang dituangkan melalui tulisan.

Memproduksi teks adalah suatu kegiatan atau usaha untuk menghasilkan sebuah teks melalui cara-cara tertentu. Dalam pembelajaran bahasa Indonesia memproduksi sama halnya dengan menulis. Sebagaimana, Menurut Dalman (2014: 3) Menulis merupakan suatu kegiatan komunikasi berupa penyampaian pesan (informasi) secara tertulis kepada pihak lain dengan menggunakan bahasa tulis sebagai alat atau medianya. Aktivitas menulis melibatkan beberapa unsur, yaitu penulis sebagai penyampai pesan, isi tulisan,saluran atau media, dan 
pembaca. Tarigan (2013:3) menyatakan menulis merupakan suatu keterampilan berbhasa yang dipergunakan untuk berkomunikasi secara tidak langsung, tidak secara bertatap muka dengan orang lain dan menulis juga merupakan kegitan yang produktif dan ekspresif. Ahmadi dalam Barus (2010:1) menyatakan menulis adalah suatu proses menyusun, mencatat, dan mengkomunikasikan makna dalam tataran ganda, bersifat interaktif dan diarahkan untuk mencapai tujuan tertentu dengan menggunakan suatu sistem tanda konvensiaonal yang dapat dilihat (dibaca).

Semi (2007:14) Menulis adalah suatu proses kreatif memindahkan gagasan ke dalam lambang-lambang tulisan. Dalam pengertian ini, menulis itu memiliki tiga aspek utama. Yang pertama adanya tujuan atau maksud tertentu yang hendak di capai.Kedua, adanya gagasan atau sesuatu yang hendak dikomunikasikan.Ketiga, adanya sistem pemindahan gagasan itu, yaitu berupa sistem bahasa.

Memproduksi teks dapat juga dikatakan membuat atau menghasilkan teks. Dalam membuat suatu teks harus memperhatikan kata-kata yang akan digunakan. Apabila dapat menggunakan kata-kata dengan tepat, maka penulis atau pembicara dapat berkomunikasi dengan pembaca atau pendengar dan dapat menyampaikan gagasan atau ide-ide dengan baik.Namun, apabila pemilihan kata kurang tepat, teks yang dibuat menjadi tidak bisa menyampaikan gagasan atau ide-ide dari penulisnya dengan baik.

Dalam Kamus Besar Bahasa Indonesia (2005:707) dijelaskan,’Kemampuan adalah kesanggupan, kecakapan, kekuatan," Tarigan (1990:1) mengemukakan bahwa "Kemampuan adalah pengetahuan apa yang dipunyai pemakai bahasa tentang bahasanyadan nilai yang merupakan objek penting." Menurut Kamus Besar Bahasa Indonesia memproduksi berasal dari kata dasar "produksi” yang berarti proses mengeluarkan hasil.

Jadi memproduksi teks adalah suatu kegiatan menghasilkan atau menciptakan sesuatu tanda kebahasaan dengan alat tulis pada suatu halaman tertentu.Berdasarkan beberapa pendapat di atas dapat disimpulkan bahwa menulis adalah salah satu keterampilan berbahasa yang mengungkapkan ide, pesan dan gagasan ke dalam suatu bentuk tulisan.Menulis harus menjadi sebuah kebiasaan dan harus menjadi kegiatan yang diminati.Kemampuan adalah kesanggupan atau kecakapan seseorang untuk memperoleh pengetahuan yang merupakan hasil dari latihan dan praktik.Kemampuan memproduksi teks eksplanasi mengarahkan pada kemampuan siswa menulis teks.Dimana pengertian memproduksi adalah menghasilkan atau mengeluarkan hasil.Kemampuan memproduksi teks eksplanasi adalah kemampuan menulis atau memahami teks eksplanasi berdasrkan isi, struktur dan ciri kebahasaannya.

Menurut Dalman (2014:6) Menulis memiliki banyak manfaat yang dapat dipetik dalam kehidupan ini, diantaranya adalah: 
a) peningkatan kecerdasan,

b) pengembangan daya inisiatif dan kreativitas,

c) penumbuhan keberanian, dan

d) pendorongan kemauan dan kemampuan mengumpulkan informasi

Menurut Barus (2010:2) Menulis sebagai kegiatan berbahasa tulis meliputi empat unsur, yakni sebagai berikut :

1) Gagasan

Dalam hal ini, gagasan adalah ide, opini, pengalaman atau pengetahuan yang diungkapkan oleh penulis

2) Ekspresi

Ekspresi adalah pengungkapan gagasan yang dilakukan sedemikian rupa sehingga dapat dipahami dengan baik oleh pembaca

3) Tatanan

Tatanan adalah aturan atau tata tertib pengembangan dan penyusunan gagasan yang biasa dipedomani penulis.

4) Sasaran

Sasaran adalah alat untuk menyampaikan gagasan, yaitu bahasa tulis yang terutama menyangkut kosakata, tata bahasaa, cara menggunakan bahsa yang efesien, efektif, dan ejaan.

Secara umum dapat dinyatakan bahwa menulis bertujuan untuk mengungkapkan dan menyampaikan gagasan secara jelas dan efektif kepada pembaca.Dalam hal ini, penulis mempunyai suatu topik yang hendak dibicarakan.

Selain mempunyai tujuan yang bersifat umum itu, menulis juga mempunyai tujuan yang bersifat khusus. Sesuai dengan bentuk-bentuk ekspresi yang telah dikemukakan pada pembicaraan terdahulu, tujuan khusus menulis dapat dibagi menjadi empat macam yakni :

1) menjelaskan atau menerangkan

2) menimbulkan citra yang sama dengan yang diamati oleh penulis tentang suatu objek

3) meninggalkan kesan tentang perubahan-perubahan sesuatu yang terjadi mulai dari awal sampai akhir cerita

4) meyakinkan atau mendesak pembaca sehingga mengubah pikiran, pendapat atau sikapnya sesuai dengan keinginan penulis.

\section{METODE PENELITIAN}

Kegiatan dalam penelitian dilakukan sebagai upaya untuk membuktikan dan menemukan sesuatu hal dengan berdasarkan pada metode yang digunakan.Dengan maksud untuk mendapatkan tujuan penelitian dengan baik.Maka metode yang digunakan haruslah disesuaikan dengan masalah yang dibahas dalam penelitian.Metode penelitian merupakan rangkaian cara atau kegiatan pelaksanaan penelitian yang didasari oleh asumsi dasar dan 
pertanyaan suatu masalah yang dihadapi. Metode penelitian memiliki sebuah rancangan untuk mencapai tjuan penelitian.Tujuan yang dimaskud untuk mengarahkan peneliti merancang sebuah kegiatan agar dapat memberikan jawaban yang sahih terhadap pertanyaanpertanyaan yang diajukan peneliti dalam rumusan masalah.Arikunto (2013:203) yang menyatakan bahwa ,'Metode penelitian adalah cara yang digunakan oleh peneliti dalam mengumpulkan data penelitiannya." Maka dalam penelitian ini, penulis menggunakan metode deskriptif kualitatif, yaitu suatu metode yang berusaha menggambarkan situasi atau gejala yang terjadi dalam keadaan nyata.

\section{HASIL PENELITIAN DAN PEMBAHASAN}

\section{Hasil Penelitian}

\section{a. Deskripsi Lokasi /Objek Penelitian}

Penelitian ini dilakukan disalah satu sekolah menengah atas yang ada di Kota Medan yaitu SMK Multi Karya.SMK tersebut beralamat di Jalan STM no 10.Objek kajiannya disesuaikan dengan rumusan masalah dalam penelitian. Pertama kemampuan memproduksi teks eksplanasi berdasarkan isi, kedua kemampuan memproduksi teks eksplanasi berdasarkan struktur, dan yang ketiga kemampuan memproduksi teks eksplanasi berdasarkan ciri kebahasaan

\section{b. Pengolahan Data Kemampuan Memproduksi Teks Eksplanasi}

Data penelitian ini diolah dengan menggunakan teknik statistik deskripsi.Pengolahan data penelitian memproduksi teks eksplanasi berdasarkan isi, struktur dan ciri kebahasaan dilakukan dengan tahapan menghitung nilai rata-rata (mean) dan mempresentasekan nilai kemampuan dengan menyusun tabel frekuensi data.

Nilai rata-rata kemampuan memproduksi teks eksplanasi berdasarkan isi, struktur dan ciri kebahasaan siswa kelas XI SMK Multi Karya adalah sebagai berikut.

$$
\begin{aligned}
M & =\frac{\sum X}{N} \\
& =\frac{2730}{40} \\
& =68,25
\end{aligned}
$$

Keterangan :

$\mathrm{M}=$ rata-rata nilai 
$\mathrm{N}=$ jumlah siswa

$\sum_{\mathrm{x}}=$ jumlah nilai seluruh siswa

Kemudian skor rata-rata ini diklasifikasikan dengan kategori penilaian untuk skala empat yang dikemukakan oleh Sudijono (2015:24) sebagai berikut.

Skor $86-100$

Baik Sekali

Skor 76-85

Baik

Skor 56-75

Cukup

Skor $10-55$

Kurang

Berdasarkan skor rata-rata yang diperoleh yaitu 68,25. Setelah diklasifikasikan dengan peringkat nilai kategori maka dapat disimpulkan bahwa kemampuan siswa memproduksi teks eksplanasi oleh siswa kelas XI SMK Multi Karya tahun pembelajaran 2016/2017 berada pada kategori cukup. Dengan kata lain siswa cukup mampu memproduksi teks eksplansi.

\section{Pembahasan Hasil Penelitian}

Berdasarkan hasil penelitian, diketahui bahwa kemampuan memproduksi teks eksplanasi oleh siswa kelas XI SMK Multi Karya tahun pembelajaran 2016/2017 dengan skor rata-rata 68,25 berada pada kategori cukup.

Ada tiga aspek penilaan dalam menilai kemampuan memproduksi teks eksplanasi, yaitu kamampuan memproduksi teks eksplanasi berdasarakan struktur, kemampuan memproduksi teks eksplanasi berdasarkan isi, dan kemampuan memproduksi teks eksplansi berdasarkan ciri kebahasaan. Berikut perolehan skor masing-masing aspek:

\section{Kemampuan Memproduksi Teks Eksplanasi Berdasarkan Struktur}

Pada aspek penilian berdasarkan struktur siswa memperoleh skor maksimal 30 dan skor minimalnya 20. Untuk mengetahui nilai rata-rata pada aspek ini jumlah skor 1010 dibagi dengan jumlah siswa 40. Jadi skor rata-rata aspek ini adalah 25,25.

Selanjutnya, untuk mengetahui nilai rata-rata kemampuan memproduksi teks eksplanasi siswa kelas XI SMK Multi Karya berdasarkan struktur termasuk dalam kategori mana, nilai rata-rata tersebut diklasifikasikan berdasarkan kategori skala empat menurut Nurgiyantoro (2013:253). Oleh karena itu, nilai rata-rata tersebut $(25,25)$ dibagikan dengan skor maksimal (30) lalu dikali dengan seratus (100). Jadi nilai rata-rata kemampuan memproduksi teks eksplanasi berdasarkan struktur adalah $\mathbf{8 4 , 1 6}$ dan termasuk dalam kategori baik. 
Berdasarkan penelitian yang telah dilakukan aspek struktur memperoleh nilai tertinggi 84,16berada pada kategori baik. Hal ini menunjukkan bahwa siswa sudah memahami dan dapat menuliskan teks eksplanasi berdasarkan strukturnya dengan sangat baik.Seperti yang yang kita ketahui struktur teks eksplanasi adalah identifikasi fenomena, rangkaian kejadian, ulasan atau penilaian.Tetapi masih ada siswa yang tidak dapat menemukan struktur teks eksplanasi secara lengkap, yaitu siswa tidak menemukan adanya struktur identifikasi fenomena dan ulasan atau penilaian.Seperti yang telah dijelaskan sebelumnya, penilaian teks eksplanasi berfokus pada struktur, isi dan ciri kebahasaan teks eksplanasi.Struktur teks eksplanasi tersebut terdiri dari identifikasi fenomena, pengggambaran rangkaian kejadian, ulasan atau penilaian. Dalam memproduksi teks eksplanasi pada struktur siswa lebih sulit dalam menulisakan identifikasi fenomena yaitu menjelaskan atau memaparkan isi teks eksplanasi yang berisi proses terjadinya suatu peristiwa, banyak siswa yang mampu menjelaskan penyebab dan proses terjadinya peristiwa, namun masih kurang tepat dalam memaparkan proses terjadinya suatu peristiwa.

Temuan penelitian di lapangan sehubungan dengan kemampuan membuat penggambaran rangkaian kejadian menunjukkan bahwa sebagian besar siswa mampu membuat penggambaran rangkaian kejadian dengan sangat baik.Sebagian besar mereka bisa menggambarkan gambaran awal tentang suatu fenomena yang diangkat dengan menjelaskan pengertian secara tepat dan benar, mampu memberikan pernyataan yang bisa memberikan jawaban atas gambaran rangkaian kejadian tersebut secara ringkas dan jelas. Dengan demikian secara keseluruhan, sebagian besar siswa mampu mengaplikasikan teori yang terkait dengan penggambaran rangkaian kejadian

Selanjutnya sehubungan dengan ulasan atau penilaian, dapat dijelaskan bahwa sebagian besar siswa hanya bisa menambahkan sudut pandangnya terhadap peristiwa, namun belum bisa menarik kesimpulan dengan tepat serta kesulitan dalam menemukan atau menghubungkan kejadian nyata yang cocok dengan peristiwa yang diangkatnya.

Aspek ini merupakan aspek dengan pemerolehan nilai paling tinggi dengan nilai 84,16 . Hal ini dikarenakan siswa benar-benar memahami struktur dari teks.Selain itu struktur sebuah teks paling mudah ditemui karena struktur sudah tergambar dalam sebuah teks.Sehingga tidak perlu pengkajian secara mendalam untuk menentukan struktur sebuah teks. 


\section{Kemampuan Memproduksi Teks Eksplanasi Berdasarkan Ciri Kebahasaan}

Pada aspek penilaian berdasarkan ciri kebahasaan siswa memperoleh skor maksimal 40 dan skor minimalnya 10.Untuk mengetahui nilai rata-rata pada aspek ini berjumlah 730 dibagi dengan jumlah siswa 40. Jadi skor rata-rata apek ini adalah 18,25.

Selanjutnya untuk mengetahui nilai rata-rata kemampuan memproduksi teks eskplanasi siswa kelas XI SMK Multi Karya berdasarkan ciri kebahasaannya termasuk dalam kategori mana, nilai rata-rata tersebut diklasifikasikan berdasarkan kategori nilai skala empat menurut Nurgiyantoro (2013:253). Oleh karena itu, nilai rata-rata tersebut 18,25 dibagikan dengan skor maksimal (40) lalu dikalikan dengan (100). Jadi nilai rata-rata kemampuan memproduksi teks eskplanasi berdasarkan ciri kebahasaannya adalah 45,63berada dalam kategori kurang.

Aspek ciri kebahasaan merupakan aspek yang memperoleh nilai terrendah dari aspek struktur dan aspek isi.Hal ini menunjukkan bahwa siswa belum memahami ciri kebahasaan yang terdapat pada teks eksplanasi. Rendahnya nilai pada aspek ini dikarenakan siswa malas membaca teks, dapat dikatakan minat baca siswa kurang, sehingga siswa hanya menuliskan apa yang dibaca sepintas saja. Selain itu kegitan memproduksi teks eksplanasi berdasarkan ciri kebahasaanya memerlukan pengkajian secara mendalam dibandingkan kedua aspek lainnya.Hal inilah yang menyebabkan nilai memproduksi teks eksplanasi sangat rendah.

Hasil penelitian juga menunjukkan bahwa kemampuan siswa berkategori kurang dalam nilai rata-rata siswa. Secara keseluruhan perhatian siswa lebih terfokus kepada struktur teks eksplanasi dan melupakan ciri kebahasaan.Dari hasil penelitian, diketahui bahwa ratarata siswa sering menggunakan tanda baca dan ejaan yang kurang tepat dalam tulisannya.Dan sebagian lainnya sering menggunakan pilihan kata (diksi) yang kurang tepat.Teks eksplanasi memiliki ciri kebahasaan "penunjuk keterangan waktu, penunjuk keterangan cara, konjungsi, kata ganti tunjuk" yang sering digunakan dalam penulisan teks adalah konjungsi contoh nya "dan. oleh" dan kata kata tunjuk "ini dan itu". Dengan demikian dapat dikatakan rata-rata kemampuan siswa dikategorikan kurang dalam mengaplikasikan teori yang berkaitan dengan ciri kebahasaan.

\section{Kemampuan Memproduksi Teks Eksplanasi Berdasarkan Isi}

Pada aspek penilian berdasarkan isi siswa memperoleh skor maksimal 30 dan skor minimalnya 20. Untuk mengetahui nilai rata-rata pada aspek ini jumlah skor 1010 dibagi dengan jumlah siswa 40. Jadi skor rata-rata aspek ini adalah 25,25. 
Selanjutnya, untuk mengetahui nilai rata-rata kemampuan memproduksi teks eksplanasi siswa kelas XI SMK Multi Karya berdasarkan isi termasuk dalam kategori mana, nilai rata-rata tersebut diklasifikasikan berdasarkan kategori skala empat menurut Nurgiyantoro (2013:253). Oleh karena itu, nilai rata-rata tersebut $(25,25)$ dibagikan dengan skor maksimal (30) lalu dikali dengan seratus (100). Jadi nilai rata-rata kemampuan memproduksi teks eksplanasi berdasarkan isi adalah 84,16 dan termasuk dalam kategori baik.Berdasarkan penelitian yang telah dilakukan aspek isi memperoleh nilai tertinggi juga yaitu 84,16berada pada kategori baik. Hal ini menunjukkan bahwa siswa sudah memahami dan dapat menuliskan teks eksplanasi berdasarkan isinya dengan sangat baik.Seperti yang yang kita ketahui isi teks eksplanasi adalah identifikasi fenomena, rangkaian kejadian, ulasan atau penilaian. Tetapi masih ada siswa yang tidak dapat menemukan isi teks eksplanasi secara lengkap, yaitu siswa tidak menemukan adanya isi identifikasi fenomena dan ulasan atau penilaian.Seperti yang telah dijelaskan sebelumnya, penilaian teks eksplanasi berfokus pada struktur, isi dan ciri kebahasaan teks eksplanasi.Isi teks eksplanasi tersebut terdiri dari identifikasi fenomena, pengggambaran rangkaian kejadian, ulasan atau penilaian. Dalam memproduksi teks eksplanasi pada isi siswa lebih sulit dalam menulisakan identifikasi fenomena yaitu menjelaskan atau memaparkan isi teks eksplanasi yang berisi proses terjadinya suatu peristiwa, banyak siswa yang mampu menjelaskan penyebab dan proses terjadinya peristiwa, namun masih kurang tepat dalam memaparkan proses terjadinya suatu peristiwa.

Temuan penelitian di lapangan sehubungan dengan kemampuan membuat penggambaran rangkaian kejadian menunjukkan bahwa sebagian besar siswa mampu membuat penggambaran rangkaian kejadian dengan sangat baik. Sebagian besar mereka bisa menggambarkan gambaran awal tentang suatu fenomena yang diangkat dengan menjelaskan pengertian secara tepat dan benar, mampu memberikan pernyataan yang bisa memberikan jawaban atas gambaran rangkaian kejadian tersebut secara ringkas dan jelas. Dengan demikian secara keseluruhan, sebagian besar siswa mampu mengaplikasikan teori yang terkait dengan penggambaran rangkaian kejadian Selanjutnya sehubungan dengan ulasan atau penilaian, dapat dijelaskan bahwa sebagian besar siswa hanya bisa menambahkan sudut pandangnya terhadap peristiwa, namun belum bisa menarik kesimpulan dengan tepat serta kesulitan dalam menemukan atau menghubungkan kejadian nyata yang cocok dengan peristiwa yang diangkatnya.

Aspek ini merupakan aspek dengan pemerolehan nilai paling tinggi dengan nilai 84,16 . Hal ini dikarenakan siswa benar-benar memahami isi dari teks.Selain itu isi sebuah 
teks paling mudah ditemui karena isi sudah tergambar dalam sebuah teks.Sehingga tidak perlu pengkajian secara mendalam untuk menentukan isi sebuah teks.

Berdasarkan hasil penelitian diperolehlah gambaran atau temuan bahwa kemampuan memeproduksi teks eksplanasi siswa kelas XI SMK Multi Karya Tahun Pembelajaran 2016/2017 dengan nilai rata-rata 68,25 berada pada kategori cukup. Dengan persentase kemampuan sebanyak 2 (5\%) siswa berada pada rentang skor 86-100 termasuk dalam kategori baik sekali, sebanyak 14 (35\%) siswa berada pada rentang skor 76-85 termasuk dalam kategori baik, sebanyak 18 (45\%) berada pada rentang skor 56-75 termasuk dalam kategori cukup, sebanyak 6 (15\%) berada pada rentang skor 10-55 termasuk dalam kategori kurang. Dari hasil kemampuan siswa dalam perhitungan diatas, jelas terlihat kemampuan siswa memproduksi teks eksplanasi dikatakan cukup, karena nilai rata-rata berada pada kategori cukup.Hal ini disebabkan siswa kurang memahami materi karena tidak mengulangi kembali pembelajaran teks eksplanasi. Selain itu, minat baca siswa kurang, hal ini berdasarkan tanya jawab peneliti terhadap siswa mengenai kesulitan mereka dalam memproduksi teks. Sehingga perlu adanya pembentukan kelompok belajar dan pembahasaan secara lebih mendalam lagi mengenai materi memproduksi teks eksplanasi khususnya pada aspek ciri kebahasaan.

\section{PENUTUP}

Berdasarkan hasil pembahasan data penelitian mengenai kemampuan memproduksi teks eksplanasi berdasarkan isi, struktur dan ciri kebahasaan oleh siswa kelas XI SMK Multi Karya Tahun Pembelajaran 2016/2017 dapat disimpulkan kemampuan memproduksi isi teks eksplansi siswa kelas XI SMK Multi Karya Tahun Pembelajaran 2016/2017 dikatakan sudah baik karena dalam memproduksi teks eksplanasi siswa sudah mengetahui isi dari teks yang teridiri dari identifikasi fenomena, penggambaran rangkaian kejadian dan ulasan atau penilaian yang sesuai dengan struktur teks eksplanasi. Kesesuaian isi terdapat pada struktur teks. Kemampuan memproduksi teks berdasarkan isi dikatakan berada dalam kategori baik dengan perolehan nilai rata-rata 84,16.

Kemampuan memproduksi struktur teks eksplansi siswa kelas XI SMK Multi Karya Tahun Pembelajaran 2016/2017 dikatakan sudah baik karena dalam memproduksi teks eksplanasi siswa sudah mengetahui isi dari teks yang teridiri dari identifikasi fenomena, penggambaran rangkaian kejadian dan ulasan atau penilaian, dari hasil kerja siswa yang sering tidak ditemui adalah identifikasih fenomena dan ulasan atau penilaian. Siswa masih 
sulit menjelaskan awal kejadian tetapi siswa bisa menggambarkan proses kejadian tersebut. Kemampuan memproduksi teks berdasarkan isi dikatakan berada dalam kategori baik dengan perolehan nilai rata-rata 84,16 .

Dan kemampuan memproduksi ciri kebahasaan teks eksplansi siswa kelas XI SMK Multi Karya Tahun Pembelajaran 2016/2017 dikatakan belum sempurna karena masih banyak siswa yang belum memahami ciri kebahasaan.Secara keseluruhan perhatian siswa lebih terfokus kepada struktur teks eksplanasi dan melupakan ciri kebahasaan.Dari hasil penelitian, diketahui bahwa rata-rata siswa sering menggunakan tanda baca dan ejaan yang kurang tepat dalam tulisannya.Dan sebagian lainnya sering menggunakan pilihan kata (diksi) yang kurang tepat, ditambah lagi minat baca siswa kurang. Kemampuan memproduksi teks berdasarkan ciri kebahasaan berada dalam kategori kurang dengan perolehan nilai rata-rata 45,63 .

\section{DAFTAR PUSTAKA}

Barus, 2010.Pembinaan Kompetensi Menulis. Medan: USU Press

Dalman, 2014.Keterampilan Menulis. Jakarta: PT Raja Grafindo Persada

Djiwandono, 2011.Tes Bahasa Pegangan bagi Pengajar Bahasa. Bandung: PT Indeks

Iskandar, 2009.Metode Penelitian Kualitatif. Jakarta: Gaung Persada

Kosasih, 2014.Jenis-Jenis Teks. Bandung: Penerbit Yrama Widya

Lagur, Novita 2012. Skripsi: Kemampuan Menulis Teks Eksplanasi dengan Menggunakan Media Gambar Seri Siswa Kelas VII SMP Negeri 2 Turi, Slamen Yogyakarta Tahun Pembelajaran 2015/2016: Universitas Sanata Dharma

Mahsun, 2014.Teks dalam Pembelajaran Bahasa Indonesia Kurikulum 2013. Jakarta: Rajawali Pers

Ningsih, Yulia 2010. Skripsi: Kemampuan Menulis Teks Eksposisi Siswa Kelas X SMA Negeri 1 Banten Tahun Pembelajaran 2013/2014: Universitas Maritim Raja Ali Haji

Priyatni, 2015.Desain Pembelajaran Bahasa Indonesia Dalam Kurikulum 2013. Jakarta: PT Bumi Aksara

Rika Kustina. 2014." Efektifitas, Pembelajaran Kooperatif Tipe Team Asisted Individualization (TAI) Dalam Materi Pengenalan Struktur Teks Eksplanasi Pada Siswa Kelas VII SMP Negeri 3 Banda" e-Jurnal Jurusan Pendidikan Bahasa dan Sastra Indonesia Universitas Pendidikan STKIP Bina Bangsa Getsempena, Indonesia, Undiksha. Volume V nomor 2. Juli- Desember 2014 
Semi, 2007.Dasar-dasar Keterampilan Menulis. Bandung: Angkasa

Sudijono, 2015.Pengantar Statistik Pendidikan. Jakarta: PT Raja Grafindo Persada

Tarigan, 2013.Menulis Sebagai Suatu Keterampilan Berbahasa 